\title{
PENGARUH PENYULUHAN TERHADAP PENGETAHUAN IBU RUMAH TANGGA MENGENAI PENGELOLAAN SAMPAH PADAT DI LINGKUNGAN PASSARANG KABUPATEN MAJENE
}

\author{
Asmuni $^{1)}$ \\ ${ }^{1)}$ Prodi S1 Kesehatan Masyarakat STIKes Bina Bangsa Majene, Sulawesi Barat \\ E-Mail: $\underline{\text { asmunirizal @ gmail.com }}$
}

\begin{abstract}
ABSTRAK.
Pengelolaan sampah menuntut UU No. Delapan Belas Tahun Dua Ribu Delapan adalah kegiatan yang sistematis, menyeluruh dan berkesinambungan yang meliputi pengurangan dan penanganan sampah. Tujuan penelitian untuk mengetahui pengaruh penyuluhan terhadap pengetahuan ibu rumah tangga mengenai pengelolaan sampah padat di Lingkungan Passarang. Manfaat penelitian yaitu menambah pengetahuan, pengalaman dan wawasan masyarakat mengenai pengelolaan sampah padat. Jenis penelitian yang digunakan dalam penelitian ini adalah jenis penelitian preeksperimental design dengan pendekatan "one-group pretest-posttest design" pengambilan tehnik pengambilan sampel yang digunakan adalah purposive sampling (pengambilan sampel berdasarkan pertimbangan) dan menggunakan uji Wilcaxon dan SPSS (Statistical Product and Service Solution). Penelitian ini dilakukan pada tanggal dua puluh dua juli sampai dua puluh empat juli dua ribu delapan belas. Analisis univariat pada distribusi umur lebih banyak dua puluh satu sampai tiga puluh tahun dan tiga puluh satu sampai empat puluh tahun sebanyak enam belas responden, distribusi pendidikan paling banyak SD/sederajatnya sebanyak dua puluh sembilan responden, distribusi pengetahuan berdasarkan pre test lebih banyak rendah sebanyak lima puluh sembilan responden dan distribusi pengetahuan berdasarkan post test lebih banyak cukup sebanyak lima puluh empat responden. Hasil dari penelitian ini menunjukkan bahwa hasil analisis uji Wilcaxon bahwa pre-post test mempunyai nilai $\mathrm{p}$-value $=$ nol koma nol nol nol $<\alpha=$ nol koma nol lima, menunjukkan bahwa ada pengaruh penyuluhan terhadap pengetahuan pengelolaan sampah padat pada ibu rumah tangga di Lingkungan Passarang, sehingga diharapkan kepada ibu rumah tangga agar dapat mengelolah sampah padat.
\end{abstract}

Kata kunci: Pengolahan Sampah, penyuluhan dan pengetahuan

\section{PENDAHULUAN}

Limbah padat atau sampah padat merupakan salah satu bentuk limbah yang terdapat lingkungan. Masyarakat awam biasanya hanya menyebutkan sampah saja. Bentuk, jenis dan komposisi sampah padat sangat dipengaruhi oleh tingkat budaya masyarakat dan kondisi alamnya. Di negara maju yang sangat peka terhadap masalah kesehatan lingkungan, sampah padat umumnya telah diatur pembuangan nya sedemikian rupa, 
sehingga hanpir setiap jenis sampah padat telah dipisahkan untuk memudahkan pengelolannya. (Arif Sumantri, 2017).

Sampah padat yang tidak dikelola sebagaimana mestinya terbukti sering menyebabkan masalah lingkungan dan kesehatan pada manusia. Antara lain dari masalah estetik, tersumbatnya saluran air yang dapat menyebabkan banjir, bahaya kebakaran, terjadinya pencemaran lingkungan, hingga meningkatnya penyakit - penyakit yang ditularkan melalui vektor (Arif Sumantri, 2017).

Oleh Karena itu, masalah pengelolaan sampah padat menjadi suatu hal yang sangat penting untuk diselesaikan. Di Indonesia dewasa ini, sedang diupayakan pengelolaan sampah padat dalam rangka menaggulangi pencemaran, mengendalikan penyakit, maupun menciptakan kota bersih dan nyaman. Namun diperlukan usaha yang lebih optimal mengingat hasilnya hingga saat ini cukup memuaskan (Arif Sumantri, 2017).

Kementerian Lingkungan

Hidup dan Kehutanan (KLHK) menilai persoalan sampah sudah meresahkan. Indonesia bahkan masuk dalam peringkat kedua di dunia sebagai penghasil sampah plastik ke Laut setelah Tiongkok. Hal itu berkaitan dengan data dari KLHK yang menyebut plastik hasil dari 100 toko atau anggota Asosiasi Pengusaha Ritel Indonesia
(APRINDO) dalam waktu satu tahun saja, sudah mencapai 10,95 juta lembar sampah kantong plastik. Jumlah itu ternyata setara dengan luasan 65,7 hektare kantong plastik atau sekitar 60 kali luas lapangan sepak bola. Padahal, KLHK menargetkan pengurangan sampah plastik lebih dari 1,9 juta ton hingga 2019.

Permasalahan sampah menjadi masalah yang belum terselesaikan dengan baik, khususnya di berbagai daerah di Indonesia. Jumlah sampah terus meningkat di setiap tahunnya. Kesadaran pemerintah dan masyarakat akan sampah harus digali agar terlepas dari permasalahan sampah.

\section{RANCANGAN PENELITIAN}

Desain penelitian yang digunakan dalam penelitian ini adalah penelitian pre-eksperimental design (rancangan-rancangan pra eksperimen) dengan pendekatan onegroup protest-postest design untuk mengetahui adanya pengaruh penyuluhan terhadap pengetahuan pengelolaan sampah padat pada ibu rumah tangga. Populasi dalam penelitian adalah Ibu rumah tangga di Lingkungan Passarang yang terdaftar 183 ibu rumah tangga. Sampel dalam penelitian ini adalah sebagian dari ibu rumah tangga yang mewakili seluruh populasi dengan jumlah 65 ibu rumah tangga. Teknik pengambilan sampel yang digunakan adalah Purposive Sampling 
(pengambilan sampel berdasarkan pertimbangan).

HASIL

\section{Analisis Univariat}

a. Distribusi Responden Berdasarkan Umur

Tabel 5.1

Distribusi Responden Berdasarkan Umur Ibu Rumah Tangga Di Lingkungan Passarang

\begin{tabular}{clcc}
\hline No & $\begin{array}{c}\text { Umur } \\
\text { Responden }\end{array}$ & (n) & $\begin{array}{c}\text { Persantase } \\
(\boldsymbol{\%})\end{array}$ \\
\hline 1 & $<20$ tahun & 3 & 4.6 \\
2 & $21-30$ tahun & 18 & 27.7 \\
3 & $31-40$ tahun & 21 & 32.3 \\
4 & $41-50$ tahun & 11 & 16.9 \\
5 & $51-60$ tahun & 7 & 10.8 \\
6 & $>60$ tahun & 5 & 7.7 \\
\hline & Total & 65 & 100 \\
\hline
\end{tabular}

Sumber : Hasil Analisis Data

Berdasarkan Tabel 5.1 menunjukkan bahwa dari 65 responden yang berumur $<20$ tahun sebanyak 3 orang $(4,7 \%)$, yang berumur 21-30 tahun sebanyak 18 orang $(28,1 \%)$, yang berumur $31-40$ tahun yang terbanyak 21 orang (32,8\%), yang berumur 41-50 tahun sebanyak 11 orang $(17,3 \%)$, yang berumur 51-60 tahun sebanyak 7 orang $(10,9 \%)$, dan orang yang berumur $>60$ tahun sebanyak 5 orang $(7,7 \%)$.

b. Distribusi Responden Berdasarkan Pendidikan
Tabel 5.2

Distribusi Responden Berdasarkan Pendidikan Ibu Rumah Tangga di Lingkungan Passarang

\begin{tabular}{clcc}
\hline No & \multicolumn{1}{c}{$\begin{array}{c}\text { Pendidikan } \\
\text { Terakhir }\end{array}$} & $(\mathbf{n})$ & $\begin{array}{c}\text { Persantase } \\
(\boldsymbol{\%})\end{array}$ \\
\hline 1 & SD/Sederajat & 36 & 55.4 \\
2 & SMP/Sederajat & 15 & 23.1 \\
3 & SMA/Sederajat & 11 & 16.9 \\
4 & Perguruan Tinggi & 3 & 4.6 \\
\hline & Total & 65 & 100
\end{tabular}

Sumber : Hasil Analisis Data

Berdasarkan Tabel 5.2

menunjukkan bahwa dari 65 responden yang berpendidikan terakhir SD/Sederajat yang terbanyak 35 orang $(55,4 \%)$, SMP/Sederajat sebanyak 15 orang $(23,4 \%)$, SMA/Sederajat sebanyak 11 orang $(17,2 \%)$, dan perguruan tinggi sebanyak 3 orang $(4,7 \%)$.

c. Distribusi responden Berdasarkan Skor Sebelum Tes (Pretest) Penyuluhan

Tabel 5.3

Distribusi Pengetahuan Responden Berdasarkan Pretest Ibu Rumah Tangga Di Lingkungan Passarang

\begin{tabular}{|c|c|c|c|}
\hline Skor & Pengetahuan & (n) & Persentase $(\%)$ \\
\hline$\geq 50$ & Cukup & 5 & 7,7 \\
\hline$<50$ & Rendah & 60 & 92,3 \\
\hline \multicolumn{2}{|c|}{ Total } & 65 & 100 \\
\hline $\begin{array}{l}\text { Rata-rata } \\
\text { (mean) }\end{array}$ & $: 13,65$ & & \\
\hline Median & $: 13$ & & \\
\hline Modus & $: 13$ & & \\
\hline $\begin{array}{l}\text { Standar } \\
\text { deviasi }\end{array}$ & $: 2,514$ & & \\
\hline
\end{tabular}

Sumber : Hasil Analisis Data 
Berdasarkan tabel 5.3 menunjukkan bahwa skor $\geq 50$ sebanyak 5 orang $(7,7 \%)$ dan skor $<50$ sebanyak 60 orang $(92,3 \%)$. Dapat disimpulkan bahwa pengetahuan ibu rumah tangga di Lingkungan Passarang sebelum tes (pre test) penyuluhan adalah kurang dengan skor rata-rata (mean): 13,65, median: 13 , modus: 13 dan standar deviasi: 2,514 .

d. Distribusi responden Berdasarkan Skor Sesudah Tes (Posttest) Penyuluhan

Tabel 5.4

Distribusi Pengetahuan Responden Berdasarkan Posttest Ibu Rumah Tangga Di Lingkungan Passarang

\begin{tabular}{lccc}
\hline \multicolumn{1}{c}{ Skor } & Pengetahuan & (n) & $\begin{array}{c}\text { Persentase } \\
(\%)\end{array}$ \\
\hline$\geq 50$ & Cukup & 54 & 83,1 \\
$<50$ & Rendah & 11 & 16,9 \\
\hline \multicolumn{2}{c}{ Total } & 65 & 100 \\
\hline Rata-rata & $: 24,94$ & \\
(mean) & $: 28$ & \\
Median & $: 29$ & \\
Modus & $: 29$ & \\
Standar & $: 5,461$ & & \\
deviasi & & & \\
\hline
\end{tabular}

Sumber : Hasil Analisis Data

Berdasarkan Tabel 5.4 menunjukkan bahwa skor $\geq 50$ sebanyak 54 orang $(83,1 \%)$ dan skor <50 sebanyak 11 orang (16,9\%). Dapat disimpulkan bahwa pengetahuan ibu rumah tangga di Lingkungan Passarang sesudah tes (posttest) penyuluhan adalah cukup dengan skor rata-rata (mean): 24,94, median: 28, modus: 29 dan standar deviasi: 5,461

\section{Analisis Bivariat}

Hasil analisis Uji Wilcaxon menunjukkan bahwa $\mathrm{p}$-value $=$ $0,000<\alpha=0,05$, menunjukkan bahwa ada pengaruh penyuluhan terhadap pengetahuan pengelolaan sampah padat pada ibu rumah tangga di Lingkungan Passarang.

Pengetahuan ibu rumah tangga di Lingkungan Passarang sebelum tes (pretest) penyuluhan adalah kurang dengan skor ratarata 13,67 dan pengetahuan ibu rumah tangga di Lingkungan Passarang sesudah tes (posttest) penyuluhan adalah cukup dengan skor rata-rata 25,08. Berdasarkan skor rata-rata diatas menunjukkan bahwa terjadi peningkatan yang signifikan setelah melakukan penyuluhan

\section{PEMBAHASAN}

\section{a. Pengetahuan Sebelum Penyuluhan}

Pernyataan yang dominan benar saat diberikan pre test (tes sebelum) penyuluhan yaitu sampah adalah suatu bahan yang terbuang atau dibuang adalah sebanyak 44 responden, hasil dari aktivitas manusia maupun alam yang sudah tidak dipergunakan lagi disebut sampah adalah sebanyak 41 responden, pemukiman penduduk, tempat umum dan tempat perdagangan merupakan salah satu sumber sampah adalah sebanyak 65 responden, sumber sampah yang 
terbesar adalah berasal dari rumah tangga adalah sebanyak 45 responden, sisa makanan dan sisa sayuran termasuk sampah berasal dari pemukiman penduduk adalah sebanyak 65 responden.

\section{b. Pengetahuan Sesudah Penyuluhan}

Pernyataan yang dominan benar saat dibenarkan post test (sesudah tes) penyuluhan yaitu suatu bahan yang terbuang atau dibuang adalah sebanyak responden, hasil dari aktivitas manusia maupn alam yang sudah tidak dipergunakan lagi disebut sampah sebanyak 65 responden, pemukiman penduduk, tempat umum dan tempat perdagangan merupakan salah satu sumber adalah sebanyak 65 responden, sumber sampah yang terbesar adalah berasal dari rumah tangga adalah sebanyak 65 responden, sisa sayuran termasuk sampah berasal dari pemukiman penduduk adalah sebanyak 65 responden, untuk menghindari perkembangan lalat dan tikus pengumpulan sampah dapat dilakukan satu atau dua kali dalam dua minggu adalah sebanyak 65 responden, persyaratan dari bak sampah untuk menampung sampah sementara adalah rapat, tertutup dan terbuat dari bahan yang kuat adalah sebanyak 54 responden, dalam penyimpanan sampah sementara perlu memperhatikan nilai-nilai kesehatan, diantaranya adalah jenis dan cara penyimpanan sampah tertentu adalah sebanyak 65 responden, lalat dapat berkembang biak dalam tumpukan sampah, khususnya sampah rumah tangga adalah sebanyak 65 responden, selain hewan-hewan yang hidup di sampah, pecahan kaca dan potongan besi juga dapat merugikan kesehatan manusia adalah sebanyak 60 responden, tikus merupakan salah satu hewan yang bersarang ditumpukan sampah basah dan sampah kering adalah sebanyak 65 responden, tifoid, kolera dan disentri adalah penyakit yang disebabkan oleh lalat yang ada di tumpukan sampah adalah sebanyak 58 responden, pengaruh negatif dari pengelolaan sampah yang baik adalah terbentuknya lingkungan yang bersih dan sehat adalah sebanyak 60 responden, tidak membuang sampah sembarang, khususnya lingkungan adalah sebanyak 65 responden, penyakit kulit yang disebabkan oleh jamur merupakan pengaruh negatif dari pengelolaan sampah yang baik adalah sebanyak 64 responden.

Sisa makanan dan sisa sayuran adalah sampah yang dapat mudah terbakar adalah sebanyak 65 responden. Logam, pecah belah atau besi termasuk golongan sampah anorganik adalah sebanyak 65 responden. Sampah yang tergolong dapat didaur ulang diantaranya adalah plastik, kaleng bekas dan kertas bekas adalah sebanyak 65 responden, dalam pengelolaan sampah yang paling benar dan tepat adalah penyimpanan, pengumpulan, 
pengangkutan dan pembuangan ke TPA (Tempat Pembuangan Akhir) adalah sebanyak 65 responden, pembuangan sampah ke badan air dapat menimbulkan pencemaran air dan dapat mengganggu pemandangan lingkungan 54 responden.

Berdasarkan status pekerjaan, diketahui bahwa sebanyak 19 responden memiliki status bekerja, sedangkan 46 responden memiliki status tidak bekerja. Menurut Khairunnisa (2011), secara umum, ibu yang memiliki pekerjaan di luar rumah cenderung tidak peduli dengan hal-hal yang berkaitan dengan urusan rumah tangga apalagi mereka sudah mempunyai orang yang akan mengurusinya. Umumnya ibu rumah tangga yang tidak bekerja tingkat pendapatan dan pendidikan yang rendah. Hal ini menyebabkan responden tidak peduli terhadap program yang telah diupayakan oleh Pemda setempat, begitu pula dengan informasi dari media elektronik tidak didapatkan karena sebagain besar tidak memiliki fasilitas elektronik seperti televisi, sehingga tidak dapat menerima informasi-informasi yang bersifat edukasi terrhadap responden.

Demikianjuga dengan tingkat pendidikan yang rendah, sehingga wawasan responden sangat minim. Pekerjaan akan menentukan status sosial ekonomi karena dari bekerja segala kebutuhan akan dapat terpenuhi. Menurut Sedarmayati (2001) yang dikutip oleh
Hardywinoti (2007) pekerjaan yang disertai dengan pendidikan dan keterampilan akan mendorong kemajuan setiap usaha sehingga dapat meningkatkan pendapatan baik, pendapatan individu, kelompok maupun pendapatan nasional. Sejalan dengan pendapat diatas dapat di jelaskan bahwa orang yang produktif dan bekerja maka ia telah nyata berpartisipasi secara nyata dan aktif dalam pembangunan.

Ibu rumah tangga yang aktif dalam pembangunan di kecamatan Bangkinang dapat diartikan selalu mempunyai kesempatan atau waku dalam melakukan kegiatan program kebersihan lingkungan yang telah diprogram oleh pemerintah daerah.

Sementara ibu rumah tangga yang tidak bekerja selalu mengupayakan kebutuhan pokok keluarganya agar dapat hidup lebih tenang dan nyaman, sehingga mengenyampingkan hal yang tidak menghasilkan bagi dirinya dan keluarganya, termasuk melakukan kegiatan gotong royong, membayar iuran kebersihan dan membeli fasilitas pengelolaan sampah salah satunya.

\section{c. Uji Hipotesis}

Hasil dari penelitian menggunakan Uji Wilcaxon menunjukkan perbandingan pengetahuan sebelum dan sesudah penyuluhan. Terdapat 1 orang dengan hasil pengetahuan setelah penyuluhan lebih rendah 
daripada sebelum penyuluhan, 2 tetap dan 61 orang mempunyai pengetahuan yang lebih baik dari penyuluhan. Setiap orang beda-beda cara menyerap ilmu ada yang satu kali diberi tahu langsung tahu, ada juga yang berkali-kali baru bisa tahu. Bagian test statistik menunjukkan hasil Uji Wilcaxon. Dengan Uji Wilcaxon, diperoleh nilai signifikan p-value $=0,000<\alpha=0,05$ dengan demikian disimpulkan terdapat pengetahuan yang bermakna antara sebelum penyuluhan dengan sesudah penyuluhan.

\section{KESIMPULAN DAN SARAN}

Kesimpulan dalam penelitian ini yakni Pengetahuan pengelolaan sampah padat pada ibu rumah tangga di Lingkungan Passarang Sebelum (pre test) penyuluhan adalah kurang dengan rata-rata tiga belas koma enam tujuh dan Pengetahuan pengelolaan sampah padat pada ibu rumah tangga di Lingkungan Passarang sesudah (post test) penyuluhan adalah cukp dengan ratarata dua puluh lima koma nol delapan serta Terdapat pengaruh penyuluhan terhadap pengetahuan pengelolaan sampah pada ibu rumah tangga di Lingkungan Passarang.

Saran dalam penelitian ini diharapkan kepada ibu rumah tangga agar lebih bisa meningkatkan pengetahuan tentang pengelolaan sampah dengan mengikuti beberapa kegiatan atau penyuluhan dalam mengolahan sampah.

\section{DAFTAR PUSTAKA}

Kamal Fitrul, 2009. Hubungan Antara Tingkat Pengetahuan dan Sikap Ibu Rumah Tangga tentang Pengelolaan Sampah dengan Perilaku Pembuangan Sampah pada Masyarakat sekitar Sungai Beringin di RW 07 Kelurahan Wonosari Kecamatan Ngaliyan Kota Semarang. (Online) http://lib.unnes.ac.id/452/1/602 3.pdf diakses pada tanggal 21 Mei 2018

Kementerian Lingkungan Hidup dan Kehutanan, 2019. Sistem Informasi Pengelolaan Sampah Nasional. (Online) http://sipsn.menlhk.go.id/?q=3 a-data-umum diakses pada tanggal 19 Juni 2019

Notoatmodjo Soekidjo. 2011. Kesehatan Masyarakat Ilmu dan Seni. Edisi Revisi 2011 Penerbit Rineka Cipta.

Notoatmodjo Soekidjo. 2012. Metedologi Penelitian Kesehatan. Penerbit: Rineka Cipta.

Nurafiyani Ifa, 2010. Pengaruh Penyuluhan tentang Pengelolaan Sampah Rumah Tangga terhadap Tingkat Pengetahuan Masyarakat RT 13 Serangan Kelurahan Notoprajan Kecamatan 
Ngampilan Yogyakarta.

(Online)

http://eprints.ums.ac.id/43093

129/Naskah\%20Publikasi.pdf

diakses tanggal 28 Mei 2018

Nuris Rizka, 2013. Hubungan antara

status pekerjaan orang tua

dengan hasil belajar siswa

siswi kelas V SDN Pendem 02

Kota Batu. (Online)

http://eprints.umm.ac.id/3725

9/3/jiptummpp-gdl-

rizkanuris-51150-3-babii.pdf

diakses tanggal 28 Mei 2018

Marwa Fara, 2013. Hubungan

Antara Pengetahuan dan Sikap dengan Tindakan Ibu Rumah Tangga dalam

Pengelolaan Sampah Rumah

Tangga di Lingkungan II

Kelurahan Istiqlal

Kecamatan Wenang Kota

Manado Tahun 2013.

(Online)

http://fkm.unsrat.ac.id/wp-

content/uploads/2013/08/jurn

al-fara-marwa-

sumah_091511009_kesling.p

df diakses tanggal $18 \mathrm{Mei}$

2018

Peraturan Presiden Republik Indonesia Nomor 97 Tahun 2017 tentang Kebijakan dan Strategi Nasional Pengelolaan Sampah Rumah Tangga dan Sampah Sejenis Sampah Rumah Tangga (Online)

Rijal Muh. 2016. Pengaruh Penyuluhan terhadap

Pengetahuan Membaca Label
Produk Kemasan pada Mahasiswa S1 Kesehatan Masyarakat Stikes Bina Bangsa Majene (Skripsi)

Rohani Lasma. 2007. Perilaku Masyarakat dalam Pengelolaan Sampah di Desa Medan Senembah Kabupaten Deliserdang dan Di Kelurahan Asam Kumbang Kota Medan. (Online)

Sari Novita \& Asti Surahma. 2017. Pengetahuan, Sikap dan Pendidikan dengan Perilaku Pengelolaan Sampah di Kelurahan Bener Kecamatan Tegalrejo Yogyakarta. (Online)

https://core.ac.uk/download/p df/132278003.pdf diakses

tanggal 17 Juni 2019

SPSS 22, 2018 User Guide Corporatur

Sopiyudin, M. 2008. Statistik untuk Kedokteran dan Kesehatan. Edisi 3: Jakarta: Penerbit: Salemba Medika

Badan Pusat Statistik. 2018. Statistik Lingkungan Hidup Indonesia 2018. Penerbit: Badan Pusat Statistik (Online)

http://www.bps.go.id diakses tanggal 20 Juni 2019

Sumantri Arif. 2017. Kesehatan Lingkungan. Edisi 4: Depok: Penerbit: Kencana

Wahab Abdul. 2013. Pengantar Riset Bidang Kesehatan, Kebidanan dan Keperawatan. 
Edisi Pertama: Yogyakarta:

Kiakaba Dipantara

Wahab Abdul. 2013. Pengantar

Statistik. Edisi Pertama:

Yogyakarta: Penerbit: Kutub

Wacana. 